Araştırma Makalesi

\title{
İngiliz Kültürel Çalışmalar Ekolü ve Medya Mahallesi Haber Programının Alımlama Analizi
}

\author{
Hakkı Akgün (Arş. Gör.) \\ Akdeniz Üniversitesi Illetişim Fakültesi \\ hakkiakgun1@gmail.com \\ Emel Arık (Doç. Dr.) \\ (iD) Akdeniz Üniversitesi İletişim Fakültesi \\ emelarik1@hotmail.com
}

Başvuru Tarihi: 07.10.2020

Yayına Kabul Tarihi: 28.11.2020

Yayınlanma Tarihi: 29.01.2021

https://doi.org/10.17680/erciyesiletisim.807087

\section{Öz}

İngiliz Kültürel Çalışmalar Ekolü'ne göre medya kapitalist sistemin en etkin ideolojik kurumlarının başında gelmektedir. İdeolojik olarak işleyen medya iletilerine karşı bireyler pasif değil, kendi anlamlarını oluşturabilme yetilerine sahip öznelerdir. $\mathrm{Bu}$ çalışmada bireylerin medyadan aldıkları mesajı doğrudan kabul eden pasif izleyiciler olmadığı varsayımı ile Halk TV'de 26.04.2019 tarihinde yayınlanan "Medya Mahallesi" adlı haber programının ekonomi bölümüyle ilgili alımlama analizi yapılmıştır. Ekonomi bölümünün seçilme nedeni araştırmanın yapıldığı tarihlerde ülke gündeminde ekonomi ile ilgili konuların büyük bir yer tutmasıdır. Örnekleme, farklı sosyo-ekonomik özelliklere sahip yedi izleyici dahil edilmiștir. Araștırma kapsamında program izleyicilerle birlikte evlerinde izlenilmiş ve ardından derinlemesine mülakat yapılmıştır. Programın izlenilmesinin ardından katılımcılara programın izleyicilerde bıraktığı izlenimleri ölçmek amacıyla önceden hazırlanmış sorular sorularak derinlemesine görüşmeler yapılmıştır. Elde edilen sonuçlar izleyicilerin medyadan aldıkları mesajı doğrudan kabul eden pasif bireyler olmadığı varsayımını doğrulamıștır. Katılımcılar medya organının kendilerine iletmek istediği mesajın farkındadır. Çalışma katılımcıların medya mesajını alımlamasında ideolojik, sosyolojik ve ekonomik konumlarının etkili olduğunu ortaya çıkarmıştır.

Anahtar Kelimeler: Gazetecilik, Kültürel Çalışmalar, İdeoloji, Alımlama Analizi. 


\title{
British Cultural Studies Tradition and the Reception Analysis of "Medya Mahallesi" News Program
}

\author{
Hakkı Akgün (Res. Asst.) \\ iD Akdeniz University Faculty of Communication \\ hakkiakgun1@gmail.com \\ Emel Arık (Assoc. Prof. Dr.) \\ Akdeniz University Faculty of Communication \\ emelarik1@hotmail.com \\ Date Received: 07.10.2020 \\ Date Accepted: 28.11.2020 \\ Date Published: 29.01.2021 \\ https://doi.org/10.17680/erciyesiletisim. 807087
}

\begin{abstract}
According to the British Cultural Studies Tradition, the media is one of the most effective ideological institutions of the capitalist system. As opposed to ideologically functioning media messages, individuals are not passive but subjects who have the ability to create their own meanings. In this study, with the assumption that individuals are not passive viewers who directly accept the message they receive from the media, a reception analysis has been made regarding the economy section of the news program "Medya Mahallesi", broadcast on Halk TV on 26.04.2019. Seven viewers with different socioeconomic characteristics were included in the sampling. Within the scope of the research, the program was watched at home with the audience and then an in-depth interview was made. The results obtained confirmed the assumption that audiences are not passive individuals who directly accept the message they receive from the media. Participants are aware of the message that the media organ wants to convey to them. The study revealed that the participants' perception of the media message was influenced by their ideological, sociological and economic positions.
\end{abstract}

Keywords: Journalism, Cultural Studies, Ideology, Reception Analysis. 


\section{Giriş}

Medya izleyicilerinin alımlama süreçlerinin analizine yönelik alımlama çalışmaları Stuart Hall'ün kodlama-kodaçımı kuramına dayanmaktadır. İngiliz Kültürel Çalıșmalar Ekolü'nün en önemli isimlerinden biri olan Hall medyanın kapitalizmin en etkin ideolojik kurumlarından biri olduğunu söyler. Medyanın ideolojik yapılanması, hegemonik söylemin pekişmesini beraberinde getirir. Doğallaştırılan ideoloji kitle iletişim araçları aracılığıyla topluma aktarılır. Medya ideolojik konumunu gizleyerek, doğal ve bağlantısız bir söylemle anlamların kitleye aktarımını sağlarken, egemen güçlerin değerlerini meşrulaştırıcı bir işlev yüklenir. Yine de anlam üzerine gerçekleşen mücadele çoğu zaman kazananın ve kaybedenin değişim gösterdiği bir denge içerir. Bu dengede kimi zaman iktidar kimi zaman da halk söylemi baskın gelebilir. Modern toplumlarda medya bu dengenin en önemli garantörlerinden biri konumundadır.

Stuart Hall'ün 'kodlama-kodaçımı' kavramı, medyanın tüm ideolojik işleyişine rağmen, bireylerin kendi öncelikleriyle anlam dünyalarını inşa etmesi açısından önemlidir. Hall'e göre medya merkezlerinden belli bir ideolojiyi gözeterek aktarılan iletiler kimi zaman yeğlendiği șekilde, kimi zaman tartışmalı kimi zaman da muhalif bir şekilde açımlanabilir. Yeğlenen okumada egemen ideolojinin istediği şekilde bir kodaçımı gerçekleştirilirken, tartışmacı okuma metnin müzakere edilmesini, hem direnişsel hem de uyumsal bir kodaçımını işaret eder. Muhalif okumada ise aktarılan ideolojik mesajın farkında olan okurun, bilinçli bir şekilde aktarılan mesajı reddi söz konusudur. Yani egemen ideolojinin tüm arzusuna rağmen, bireyler kendilerine gönderilen mesajları yeğlendiği şekilde değil, kendi ideolojileri doğrultusunda açımlayabilirler (Hall, 1999a, s. 204).

$\mathrm{Bu}$ model özellikle televizyondan aktarılan mesajlara sıklıkla uyarlanmış ve belli profesyonel ideolojiler ekseninde hazırlanan iletilerin çoğu zaman çoğul anlamlar içerebileceğini gözler önüne sermiştir. Medya profosyonelleri ustalıkla ideolojik amaçlarını gizleyerek iletilerini gizlemelerine karşın, halk da kendi anlam dünyasında bu mesajları reddedebilme yeteneğine sahiptir. "Program yapımcıları izleyicileri belli anlamları yeğlemeye özendirmek için tüm kodlama beceri, yetenek ve bilgilerini kullanabilirler ama kod açımı edilgin değil, etkin bir süreç olduğu için bu 'yeğleme' kodlayıcıların iktidarının bir güvencesi değil, bir iktidar girişimidir; yani kod açımı sırasında izleyicinin pazarlığa oturacağı bir tekliftir" (Mutlu, 1994, s. 220).

Hall'ün modeli, özellikle televizyon programlarının toplum tarafından nasıl algılandığı noktasında önemli ipuçları sunar. Gücü kaynağa atfeden bir iletişim modelinden, gücü hedef kitleye veren bir bakış açısıyla şekillenen modeli, halkın seçme özgürlügüne vurgu yapar. Medya metinlerinin toplum nezdinde nasıl algılanacağında esas belirleyici olan nasıl sunulduğu değil, halkın onu nasıl algıladığıdır. Dolayısıyla metinler her zaman planlandığından farklı algılanabilme tehdidiyle karşı karşıyadır.

Bu çalışmada Halk TV'de 26.04.2019 tarihinde yayınlanan "Medya Mahallesi” adlı haber programının ekonomi bölümüyle ilgili alımlama analizi yapılmıştır. Yedi katılımcıyla ayrı ayrı gerçekleștirilen program seyrinin ardından katılımcıların programla ilgili anımsama ve alımlamalarını belirlemek üzere derinlemesine görüşmeler yapılmıştır. Katılımcıların yorumları, içinde bulundukları ideolojik, sosyo-ekonomik ve bireysel faktörler ile birlikte analiz edilmiștir. Çalışmanın kuramsal kısmı alımlama araştırmalarının sıkça kullanıldığı İngiliz Kültürel Çalışmalar Ekolü ile sınırlı tutulmuştur. Bu sınırlamanın nedeni medya metinlerine yönelik bir alımlama analizi olmasıdır. 


\section{İngiliz Kültürel Çalışmalar Ekolü ve Tarihsel Temelleri}

Kültürel Çalışmalar 1964'te Birmingham Üniversitesi bünyesinde yer alan Çağdaş Kültürel Araştırmalar Merkezi'nde temellenen ve kültürün yaşadığı değişimi sorgulayan bir grup entelektüelin çabalarıyla dünyaya yayılmıştır. Richard Hoggart, Edward P. Thompson, Raymond Williams ve Stuart Hall ekolün en önemli teorisyenleridir. Kültürel çalışmalar farklı sosyal bilim disiplinlerinden yararlanarak; kültür üzerine çalışan bir grup sosyal bilimcinin birlikteliğini işaret eder. Bu yüzden çoğu zaman inter-disipliner hatta multidisipliner olarak tanımlanmaktadır.

Williams, Kültür ve Toplum kitabında sosyal bilimcilerin kitleleri aşağıladıklarını, dolayısıyla kendileri dışındaki bir 'kütle' olarak tanımladıklarına dikkat çekerek şu tespiti yapar: "Kitle oldukça komplike bir terimdir. Kendimizi, arkadaşlarımızı, iş arkadaşlarımızı ve yakın çevremizi kitle olarak görmeyiz de kitleleri hep 'diğerleri' olarak tanımlamaktan hoşlanırız. Kitle sözcüğü daima 'ötekini' çağrıştırır. Başka insanlar da bizleri kitle olarak tanımlarlar. Kitleler diğer insanlardır. Aslında kitleler yoktur, sadece insanları kitleler olarak görme biçimleri vardır” (Williams, 1993, s. 16). Williams'a göre, kültür sıradandır: Başlangıç noktamız bu olmalıdır. Her insan topluluğunun kendine ait şekil, amaç ve anlamları vardır. Her insan topluluğu bunları kurumlarda, sanatlarda ve öğretilerle ifade eder" (Williams, 1980, s. 4).

Raymond Williams, İngiliz Kültürel Çalışmalar Ekolü'nün Batı Marksizmiyle; özellikle Gramsci, Voloshinov ve Althusser'in düşünceleriyle ilişkilenmesinde son derece önemli bir rol oynamıștır. Örneğin "Marksizm ve Edebiyat"ta Gramsci'den hareketle kendi hegemonya kuramının ana hatlarını sunmuştur (Williams, 1990). Hegemonyanın ve kitlelerin belirli bir düzene rızalarının hiçbir zaman nihai ve tartışılmaz olmadığını söyleyen Williams, hegemonik pratiklerin zengin ve çelişkili doğaları olduğunu vurgulamıştır. Williams'ın hegemonya analizi daha sonraki yıllarda Hall ve diğer isimler tarafından geliştirilmiştir.

Stuart Hall ekolün bir diğer önemli teorisyenidir. İdeoloji ve kültür arasındaki ilişkiye odaklanan Hall'e göre Marx'ın sınıf mücadelesi kavramı, modern toplumlarda yeniden gözden geçirilmeli ve bağımlı sınıfların etkinliği göz ardı edilmemelidir. "Ekonomi-politik yaklaşımının anlam için girilen mücadelede söyleyecek sözü olmadığını” kabul eden Hall'a göre, bu yaklaşımın "ideolojinin toplumsal özneleri nasıl inşa ettiği ya da onları toplumsal ve siyasal pratiklerle ilişkili olarak nasıl konumlandırdığına ilişkin hiçbir fikri yoktur" (Hall, 1997, s. 95). Hall'a göre, "sıradan insanlar kültürel aptallar olmadıklarına göre, popüler kültür biçimlerinde kendi hayatlarına ilişkin gerçeklerin nasıl temsil edildiğinin de farkındadırlar" (Özbek, 1994, s. 89). Hall medya metinlerinin anlamları üzerindeki mücadeleyi, kültürel bir müzakere olarak görür ve kimi zaman güçlünün, kimi zaman da zayıfın kendi okumalarını yapabileceğini iddia eder. Dolayısıyla kültürel alan da bağımlı sınıflarla, egemen sınıfların bir mücadele alanıdır ve bu gerilimin hiçbir zaman mutlak galibi bulunmamaktadır.

Hall kitle iletişim araştırmalarında 1940'lı yıllardan başlayarak, 1960'lara kadar egemenliğini koruyan "ana akım” Amerikan davranışçı yaklaşımdan "eleştirel” yaklaşıma geçişin çok önemli bir dönüşüm olduğunu vurgular. Hall'a göre ana akım ve eleştirel yaklaşım arasında hem kuramsal bakış açıları hem de siyasal tavırları açısından derin bir uçurum vardır. İki yaklaşımı birbirinden ayıran en önemli noktalardan biri ise ana akım yaklaşımlar gözlemlenebilir davranışlara ve davranış değişikliklerine odaklanırken; eleştirel yaklaşımın odağına ideoloji ve egemen iktidar ilişkilerini almasıdır (Hall, 1999b, s. 78). 
Kültürel Çalışmalar, kavramların anlamları ve ilişkileri üzerinde yoğunlaşmakta, anlamları belirlemeye çalışmaktadır. İnsanlar, yalnızca anlam yapılarından yararlanmamaktadır; insanlar dünyaya anlam verdikleri ve eylem yaptıkları sürece anlam sistemlerinden, kültürel farklılık modellerinden, şemalardan ya da yorum repertuvarlarından yararlanmaktadırlar. Bu nedenle birincil olarak yorum, anlam söylemi ya da yapıları için eylemin ya da konuşma esaslarının nasıl kullanıldığı araştırılmaktadır. Realite, insanların günlük yaşamlarında yöneldikleri anlam yorumu ve yorum kuralları ile ilintilendirilmektedir. Realite insanlar için anlamlar aracılığı ile kurulmaktadır. Yaşam ve sosyal etkinlikler, kural olarak işaretleme sürecine bağımlıdır; bu anlamların, dil sistemi aracılığıyla ortaya konulmasıdır (Alver, 2011, s. 244).

\section{Kültürel Çalışmalar ve Medya Analizleri}

Kültürel Çalışmalar Ekolü özellikle modern toplumlarda ideolojinin rolünü sorgulamış ve farklı ideolojik geleneklerin kültürel pratikleri nasıl oluşturduğu üzerinde durmuştur. Öncesinde izleyiciler ya da okuyucular egemen söylemin etkisinde güdüp-yönetilebilen bir konumdayken, sıradanlığı ve doğallığı olumlayan Kültürelciler ile birlikte etkin izleyici yaklaşımı gündeme gelmiş ve çoğul okumalar kültürel haritada yerini almıştır. Özellikle Stuart Hall ve ardından gelen David Morley, Ien Ang gibi isimler medya ideolojileri yerine izler kitlenin kendilerine aktarılan mesajları nasıl alımladıkları üzerinde durmuşlardır.

70'li yıllar boyunca semiyolojinin etkisi ve ideoloji teorisi kültürel çalışmaların medya analizlerindeki yönünü belirleyen en temel kavramlar olmuşlardır. Bu yaklaşım, temel olarak Hall'ün "Encoding/Decoding" modeline dayanır. Kuram, her ne kadar televizyon düşünülerek formülize edilmişse de farklı bir kitle iletişim aracına da uygulanabilir. $\mathrm{Bu}$ teoriye göre, alıcılar satır aralarını okuyabilir, hatta mesajın amaçlanan yönünü tersine döndürür ve bozabilir. Hall'a göre, egemen söylemler içinde kodlanan metinler, izleyici tarafından tercih edilen anlamın tersi yönde okunabilir (Hall, 2005). Bu makale merkezin birçok araştırmasını televizyona yönlendirmiş ve "etkin izleyici" teorisinin oluşmasını sağlamıştır. "Bu yaklaşım 80'li ve 90'lı yıllarda medya metinlerinin dizilerde, romanlarda, haberlerde ve eğlence programlarında anlam oluşturma sürecini açıklamaya yönelik çalışmalarına kaynaklık etmiştir. Bu çalışmalar, hegemonik söylemin oluşmasında medyanın oynadığı rolü işaret ederken, aynı zamanda hakim söylemi izleyicilerin hangi noktalarda zaafa uğratabildiğini de gözler önüne sermektedir" (Casey, Casey, Calvert, French, \& Lewis, 2002, s. 19).

Hall'ün makalesinin ampirik açıdan ilk sınanması İngiliz araştırmacı David Morley'in Nationwide izleyici alımlama ölçümü çalışmasıyla gerçekleşmiştir. Morley ve ardından Fiske'in çalışmalarında Hall'ün etkisi apaçık görünmektedir. Morley BBC'de yayınlanan bu haber programının iki farklı versiyonunu, 29 farklı eğitim ve statü düzeyine sahip 2 ile 13 arası kişiden oluşan küçük gruplara seyrettirmiştir. Bu çalışmayla Morley, izleyicilerin anlam üretimleri ile mevcut kültürel konumları arasındaki bağlantıyı ve ırk, cinsiyet, sınıf gibi kültürel faktörlerin tüketim pratiklerine nasıl yansıdığını ortaya çıkarmaya çalıșmıştır. Çalışma Hall'ün de görüşlerine paralel olarak metnin farklı bağlamlarda aynı şekilde okunamayacağı varsayımını sınamayı amaçlar. Morley’e göre, "iletilen mesajın izleyici nezdindeki potansiyel anlamlarını anlayabilmek için izleyicilerin kültürel anlam haritalarına ihtiyacımız vardır. Bu harita mesajın gönderildiği çeşitli kültürel göndergeleri ve farklı katmanlarda farklılık gösterecek sembolik kaynakları bize sunar. Bu sayede mesajın anlam üretimi ve metin içerisindeki kodların izleyiciler tarafindan yorumlanması süreci daha iyi kavranabilir" (Morley, 1986, s. 486). Morley, Hall'ün çalışmalarını takip ederek, izleyicilerin kod açım sürecine çeşitli faktörlerin etki ettiğini ileri sürer. Bu faktörler; sınıf, 
cinsiyet, yaş, tecrübe, kültürel kimlik ve mesaj alım anındaki konumlanmadır. "Morley'in çalışması sonucunda görülmektedir ki, grup üyeleri arasında önemli farklılıklar olmasına rağmen, metni okuma ve yorumlamada grup üyeleri arasında çok az görüş ayrılığı ortaya çıkmıştır" (Turner, 1992). Bu da, her metnin farklı bağlamlarda mutlaka farklı okunacağı teorisini mutlak doğrulamayan, fakat izleyicinin de iletişim sürecindeki konumunun sadece "pasif tüketici" olmadığını imleyen bir sonuçtur. Morley, aktarılan iletilerin farklı şekillerde kodaçımına uğratılabileceğini ve farklı okuma potansiyellerine sahip olduğunu dile getirmektedir.

Kültürel çalışmalar içerisinde medya mevcut iktidar ilişkileri ve yöneticilerin hegemonya tesisi içerisinde ele alınmakta olup, metinsel yapılaşma, metin içerisinde farklı söylemlerin tesisi, eklemlenme süreçleri, izleyicinin okuma ve medya içeriğini tüketim pratikleri gibi konular üzerine odaklanılmaktadır. Kültürel Çalışmalar'a gelinceye kadar Marksist eleştirel gelenek içerisinde medya metinleri daha çok üretim aşamaları ile ilgili olarak düşünülmüş ve hem araçcı yaklaşım içerisinde hem de ekonomi politik yaklaşım içerisinde bu metinlerin okuyucusu olan birey ve gruplar başlıca araştırma konusu olmamıştır (İnal, 1996, s. 43). Kültürel Çalışmalar'a kadar medya metinlerini alımlayan kitlenin güçsüzlügünden dem vurulmuş ve dayatılan ideoloji karşısında savunmasız olduğu varsayılmıştır. Kitleye ve kültüre yüklediği anlamla Kültürel Çalışmalar; metnin esas anlamının tüketilme anında ortaya çıkacağını ileri sürmüş ve kitlenin kendi özgür seçimini yapabilme yetisine sahip bireylerden oluştuğunu imlemişlerdir. Kültürel Çalışmalar, medyanın ekonomi politiğine yoğunlaşmak yerine medya metinlerinin ideolojik ve dilsel yapısına çok daha fazla dikkat çekmiş; izleyicileri medya karşısında pasif bireyler olarak gören anlayışın yerine daha aktif konumda olan bir izleyici anlayışını ortaya koymuştur. Kültürel çalışmalar geleneği içinde yapılan bir dizi metin analizi hangi söylemlerin medya metinlerinde hegemonik ideoloji doğrultusunda yeniden üretildiğini ve hangilerinin muhalif tarzda okunarak ters çevrildiğini, metin analizleri yoluyla ortaya çıkarmaktadır (Arık, 2004).

\section{Medya Mahallesi Programının Alımlama Analizi}

Çalışmanın analiz bölümünde ilk olarak 26.04.2019 tarihinde yayınlanan Medya Mahallesi adlı haber programının alımlama analizi yapılarak programda iletilmek istenen temel kodlar değerlendirilmiş ve ardından katılımcıların programla ilgili farklı kod açımları analiz edilmiştir.

\section{Araştırmanın Yöntemi}

Son yıllarda sosyal bilimler alanında ön plana çıkan alımlama analizi, göndericinin alıcıya ilettiği mesajın kodaçımı esnasında hangi anlamlar bağlamında açımlandığını keşfetmeye çalışan bir araştırma yöntemidir. Stuart Hall'ün kodlama-kodaçımı modelinden temellenen alımlama analizlerinde, izleyicilerin kendilerine aktarılan iletileri nasıl anlamlandırdıkları üzerine durulmakta, izleyici aktif olarak konumlandırılmaktadır. Hall'ün yeğlenen, tartışmacı ve muhalif olarak tanımladığı farklı okuma biçimlerini somutlaştırarak ortaya koymayı amaçlayan alımlama analizi, izleyicilerin özgün algılama biçimlerini ortaya çıkarması açısından alana dinamizm kazandıran yöntemlerin başında gelmektedir.

Alımlama, izleyenlerin medya iletileriyle ilgili yorumları, kod açımlamaları, okumaları, anlam üretimleri, algıları ya da kavrayıșlarına işaret eden genel bir kavramdır (Şeker, 2009, s. 106). Alımlama analizinde anlamın aktif olarak sosyal aktörler tarafından yapılandırıldığı düşünülür. Bu anlamda içerik, bireylerin belli bir hikayeyi ya da metni nasıl 
yorumladıklarını belirlemez. Bilton'a göre anlam üretimi onun tüketimini gerektirmez (Bilton vd., 2008). Daha ziyade çok değişik sosyal ve kültürel faktörler yorumlamayı belirler (Şeker \& Tiryaki, 2013, s. 201). Jensen ve Rosengren'e göre alımlama analizi, medya mesajlarını kültürel ve umuma yönelik șekilde şifrelenmiş söylemler olarak görür, izleyiciler ise anlam üretiminin vasıtalarıdır (Jensen \& Rosengren, 2005, s. 66). John Fiske de izleyiciyi kendi anlamlarını üreten bir özne olarak görür ve alımladığı eylemin yazarı olduğunu ileri sürmektedir (Fiske, 1999, s. 49).

Alımlama analizi geleneksel iletişim araştırmalarında belli değişkenlerle az ya da çok düzenli bir biçimde gerçekleștiği varsayılan alımlama sürecini, daha karmaşık ve etkin bir süreç olarak kavramsallaştırmış, izleyicilerin anlam üretim sürecinde anlam üretimine fiilen katıldığını belirterek iletişim araştırmalarının asal kategorisi olarak alımlayıcıları öne çıkarmıştır. Bu sayede alımlama analizi "etkin izler kitle" kavramının izinden giderek, izleyicileri medya mesajlarının tüketicisi konumundan anlamların üreticisi konumuna getirmiştir (Mutlu, 1994, s. 20).

$\mathrm{Bu}$ çalışmada okurların ürettikleri anlamları keşfetmek amacıyla her görüşmeciyle derinlemesine mülakat yapılmış ve onların iletilen mesajlardan ne anlamlar çıkardığı sorgulanmaya çalışılmıştır. Çalışmada izleyicilerin medya metinlerini alımlama ve anımsamalarını tespit etmek için Halk TV'de yayınlanan Medya Mahallesi adlı haber programının ekonomi ile ilgili bölümü seçilmiştir. Bu konunun seçilme nedeni ilgili dönemde Türkiye ekonomisinde sorunların artması ve dolayısıyla ülke gündeminin yoğun olarak ekonomi konularından oluşmasıdır. İlgili programın mevcut siyasi iktidara muhalif olması, ideolojik bir boyutunun bulunması ve aktardığı mesajların Stuart Hall'un "kodlama kodaçımı" kuramı çerçevesinde farklı şekillerde okunabilme ihtimalinin olması örneklem olarak seçilme gerekçelerini oluşturmaktadır.

Adalet ve Kalkınma Partisi hükumetine muhalif bir yayıncılık yapan Halk TV'de yayınlanan Medya Mahallesi adlı haber programı ekonominin derinlemesine tartışıldığı bir program olduğu düşüncesi ve bireyin muhalif yayın organlarındaki yayınları nasıl alımladıklarını ölçümlemek amacıyla tercih edilmiştir. Medya Mahallesi her sabah saat 11.00 'de yayınlanan ve genellikle gündemdeki konular üzerine yayın yapan bir haber programıdır. Programın 26 Nisan 2019 tarihinde yayınlanan bölümü Youtube adlı video izleme sitesinden yedi katılımcının evlerinde onlarla birlikte izlenmiştir. İzleme bittikten sonra katılımcıların tümüyle bireysel olarak derinlemesine görüşme gerçekleştirilmiştir. Ayarca, katılımcıların kimlik bilgileri, araştırma etiği doğrultusunda metin boyunca kodlanarak belirtilmiștir (Katılımcı 1: K1).

İzleme öncesinde programda aktarılanlar ile ilgili soru formu oluşturulmuş, katılımcıların programın içeriğini anımsama ve alımlaması saptanmaya çalışılmıştır. Katılımcılara sorulan çeşitli sorularla programı yeniden anlatmaları istenmiş, konuk seçimi, akıllarında kalan en önemli bilgi ve programın aktardığı mesaj gibi başlıklarla programın alımlanma ve anımsanma boyutu analiz edilmiştir. Ayrıca, Medya Mahallesi programı ve Halk TV'nin izlenme ya da izlenmeme durumu sorgulanmıștır. Katılımcılara ülkedeki ekonomik durum ile ilgili düşünceleri, kişilerin ekonomik durumlarındaki değişim ve hükumetin ekonomi konusunda "olumlu" veya "olumsuz" icraatlarıly ilgili sorular sorulmuştur. Bu soruların sorulma nedeni araştırmaya katılan izleyicilerin programı izledikten sonra ürettikleri anlam ile kişisel ekonomik durumları ve düşüncelerinin uyuşma düzeylerini tespit etmektir. Araştırmaya dahil edilen bireylerin farklı eğitim, yaş, cinsiyet ve sosyoekonomik gruplardan oluşmasına dikkat edilmiştir. Katılımcılar, işçi, memur, turizmci, 
öğrenci, ev hanımı, esnaf ve emekli gibi geniş bir meslek grubunu oluşturmaktadır. Eğitim düzeyleri ilkokuldan üniversite eğitimine kadar uzanmaktadır. Dört erkek ve üç kadından oluşan katılımcıların yaşları 23-59 aralığındadır. Katılımcıların aylık gelirleri 1000 ile 23000TL arasında değişim göstermektedir. Örneklemin farklı sosyo-demografik özelliklere sahip bireylerden oluşturulmasının nedeni izleyicilerin ürettiği anlam ile sosyal konumları arasında bağlantı kurulabileceği düşüncesidir. Araştırmaya dahil edilen katılımcıların ideolojik ve sosyo ekonomik özellikleri aşağıda yer alan tablodaki gibidir (Tablo 1):

Tablo 1. Katılımcıların ideolojik ve sosyo ekonomik özellikleri

\begin{tabular}{|l|l|l|l|l|l|l|}
\hline Kod & Cinsiyeti & Yaşı & Eğitim düzeyi & Mesleği & Aylık geliri & $\begin{array}{l}\text { Hükumete } \\
\text { bakışı }\end{array}$ \\
\hline Katılımcı 1 & Erkek & 37 & Üniversite & Turizmci & 23000TL & Olumsuz \\
\hline Katııımcı 2 & Kadın & 23 & Üniversite & Öğrenci & 1000TL & Olumsuz \\
\hline Katıımcı 3 & Kadın & 42 & Lise & Memur & 4300TL & Olumsuz \\
\hline Katıımcı 4 & Erkek & 29 & Üniversite & İşçi & 2400TL & Olumsuz \\
\hline Katııımcı 5 & Erkek & 59 & Lise & Emekli & 2000TL & Olumlu \\
\hline Katıımcı 6 & Erkek & 45 & Lise & Esnaf & 3000TL & Olumlu \\
\hline Katııımcı 7 & Kadın & 51 & İlkokul & Ev Hanımı & 3600TL & Olumlu \\
\hline
\end{tabular}

\section{Medya Mahallesi Programının İçeriği}

Alımlamanın izleyici ile medya metninin etkileşiminin bir ürünü olduğu düșüncesinden hareketle bu bölümde izleyici alımlamasının sağlıklı olarak ölçümlenebilemesi için Medya Mahallesi adlı haber programının alımlama analizi yapılmıştır. Program sunucu Ayşenur Arslan'ın konuyla ilgili genel bir girişiyle başlamış ve gündemdeki konular hakkında konuğun görüşlerine yer verilmiştir. Ülkedeki ekonomik krizin konu edildiği bölümde Ayşenur Arslan konuk olarak Sözcü gazetesi ekonomi yazarı Murat Muratoğlu ile programı sürdürmüştür. Muhalefet konumundaki Cumhuriyet Halk Partisi'ne yakınlığı ile bilinen Halk TV'de yine muhalefete yakınlığıyla bilinen Sözcü gazetesinin ekonomi yazarının konuk edilmesi programın nesnelliği açısından sorgulanması gereken bir unsurdur.

Sunucu Ayşenur Arslan programın başında dolar/Türk lirası kuru ve işsizlik rakamları gibi ekonomideki "kötü gidişatı" gösteren verileri grafikler halinde izleyiciye sunmuştur. Doların Türk Lirası karşısında son bir ayda \%9 değer kazandığını belirten konuk Murat Muratoğlu'na sunucu Ayşenur Arslan bunun işsizliği artıracağına dikkat çekerek katkıda bulunmuştur. Programda Mimar ve Mühendis Odaları Birliği'nin 91 bin mühendisin ișsiz olduğunu belirten araştırmasına atıfta bulunulmuş ve üniversitelerden mezun olan öğrencilerin iş bulamadığı ön plana çıkarılmıştır. Böylelikle programın ana mesajını oluşturan "ekonomideki kötü gidişat" farklı kurumların verileriyle desteklenmiş ve izleyici ikna edilmeye çalışılmıştır. Konuk Murat Muratoğlu, Türkiye İstatistik Kurumu verilerinin manipülatif olduğunu, işsizlik rakamının \%14,7'nin çok üzerinde olduğunu iddia ederek devletin resmi kurumlarının vatandaşa doğru bilgi vermediği ve vatandaşı kandırmaya çalıştığını ima etmiştir.

Programın önemli bir bölümünde Hazine ve Maliye Bakanı Berat Albayrak’ın açıkladığı "Yeni Ekonomi Programı"nda yer alan bilgilerin gerçekleri yansıtmadığına ve verilen hedeflerin tutturulamayacağına vurgu yapılmıştır. Bu görüşü desteklemek amaciyla programda Financial Times gazetesinin 18.04.2019 tarihinde Türkiye'nin döviz rezervlerinin tükenmek üzere olduğunu belirten haberine atıfta bulunulmuştur. 
Haberde Türkiye Cumhuriyet Merkez Bankası'nın seçimlerden önce Türk Lirası'nın değerini korumak için giriştiği "swap operasyonu"nun rezervleri açıklanandan daha düşük seviyeye çektiği belirtilmiştir. Programda konuk olan Murat Muratoğlu, bu haberi olumlayarak hükumetin güven kaybına uğradığını ima etmiştir.

Program sunucusu Ayșenur Arslan, “iktidar medyası”nın gazetecilik değerleri açısından yerlerde süründüğünü ifade ederken aynı zamanda izleyiciye kendilerinin tarafsız olduğu mesajını da vermeye çalışmıştır. Konuk Murat Muratoğlu ise bu tartışmaya Halk TV ve Sözcü gazetesi dışında bütün büyük medya kuruluşlarının iktidarın emrinde olduğunu belirterek destek vermiștir. Görüldügü üzere programın hakim kodlarının, konuların, konuk seçiminin ve sunucunun tutumunun hükumetin icraatlarını olumsuzlamaya yönelik kurgulandığı söylenebilir. Dolayısıyla Medya Mahallesi programının izleyicilerde hükumetin ekonomiyi kötü yönettiğine yönelik bir algı yaratma çabasında olduğu saptaması yapılabilir.

\section{Etik Kurul İzni}

Akdeniz Üniversitesi Rektörlüğü Sosyal ve Beşeri Bilimler Bilimsel Araştırma ve Yayın Etiği Kurulu 16/10/2020 tarih ve 17 sayılı toplantısında alınan karar çerçevesinde çalışma etik açıdan bir sakınca içermemektedir.

\section{Bulgular ve Analizi}

Çalışmanın bu bölümünde Halk TV'de 26.04.2019 tarihinde yayınlanan Medya Mahallesi adlı haber programının izleyiciler tarafından alımlanmasına yönelik önceden hazırlanan sorulara ve izleyicilerin verdiği yanıtlara yer verilecektir. Sorulan sorular ve izleyicilerin verdiği cevaplar şu şekildedir:

*Medya Mahallesi programını ya da Halk TV'yi düzenli olarak takip ediyor musunuz?

K1: "ikisini de takip etmiyorum, ilk defa izledim."

K2: "Halk TV'nin bazı programlarını internet üzerinden takip ediyorum ama bu programı değil."

K3: "Evet genellikle izliyorum."

K4: "Denk geldikçe izliyorum."

K5: "Hayır takip etmiyorum."

K6: "Hayır takip etmiyorum."

K7: "Sürekli hükumeti kötüleyen taraflı bir televizyon kanalını asla izlemem."

Program hakkında görüşleri sorulan izleyicilerin o programın takipçileri olup olmadıkları veya programın yayınlandığı kanala yönelik eski tutumları izleyici alımlamasında önemli bir etken konumundadır. Araştırmaya konu olan örneklemde üç kişi kanalı ya da programı takip etmediğini belirtirken, üç kişi takip ettiğini belirtmiştir. Bir kişi ise "sürekli hükumeti kötüleyen taraflı bir televizyon kanalını asla izlemem" yanıtını vererek kanala yönelik negatif bir tutum benimsediğini ortaya koymuştur.

*Program içeriğinde hatırladığınız ilk şey nedir?

K1: "Doların yükseleceği ima edilmişti, bu sene turizm bereketli geçecek."

K2: "İşsiz mühendisler."

K3: "Hükumetin yaptığı israflar."

K4: "Artan işsizlik."

K5: "Türkiye'nin azalan döviz rezervleri." 
K6: "Konuğun aşırı kötümser tavrı."

K7: "Sunucu saldırgan bir tutum içerisindeydi, devlete saldıracak yer arıyordu."

İzleyicilerin ifadelerinden de anlaşılacağı üzere programa yönelik izleyicilerin akıllarına gelen ilk bilgiler bireylerin ideolojik ve sosyo-demografik özelliklerine göre farklılıklar göstermektedir. Programın izleyiciye gönderdiği kodlar farklı şekillerde karşılık bulmuş ve bu kodlardan farklı anlamlar çıkarılmıştır. Turizm sektöründe çalışan izleyici aklında kalan ilk şey olan doların yükseleceği imasını olumlu olarak karşılarken, izleyicilerin çoğunluğu kendileri için negatif olan bir durumu hatırlamaktadır.

*Programa konuk olarak katılan ekonomi yazarının söylediklerini nasıl değerlendiriyorsunuz?

K1: "Oldukça iddialı konuşuyor ama bence bazı şeyleri çok abartıyor. Ülkemizin daha kötüye gideceğini sanmiyorum."

K2: "Ekonominin sorunların cesurca dile getirdi."

K3: "Gerçekleri söyledi."

K4: "Kötümser bir bakış açısıına sahip."

K5: "Çok taraflıydı."

K6: "Merkez Bankası rezervlerine yönelik gazetede çıkan bir haberi kesinlikle doğruymuş gibi göstermesi yanlıştı. Hükumetten gelen açılklamalara hiç değinilmedi."

K7: “Kendi kötü düşüncelerini insanlara empoze etmeye çalışlyor. Zaten Sözcü’nün yazarından da bu beklenirdi."

Katılımcıların programa katılan konuk hakkında çok farklı tutumlara sahip olduğu görülmektedir. Konuk tarafından dile getirilen söylemler katılımcılar tarafından hakim, müzakereli ve karşıt okumayla karşılanmıştır. Verilen cevapların kişilerin ideolojik tutumlarıyla örtüştügü görülmektedir.

*Programa konu olan Kanal İstanbul Projesi ile ilgili ne düşünüyorsunuz?

K1: "Gereksiz buluyorum, o parayla daha iyi yatırımlar yapılabilir."

K2: "Ülkenin çöpe atacak parası yok."

K3: "Bence zaten olmayacak bir proje, gündem değiştirmek için kullanıllyor."

K4: "O kadar paraya birkaç tane fabrika açılsa daha iyi olur."

K5: "Hep olumsuz yanları anlatıldı, o kadar da kötü olmayabilir."

K6: "Ekonomik olarak getirisine hiç değinilmedi."

K7: "Programda anlatılanların tamamen yalan ve abartma olduğunu düşünüyorum, bunlar ülkenin iyiliğini istemiyorlar."

Kanal İstanbul Projesi ile ilgili olarak verilen cevaplara bakıldığında katılımcıların programın olumsuz bir gelişme olarak kodladığı projeye karşı kendi ideolojik tutumları ve sosyo-ekonomik konumları çerçevesinde farklı kodaçımları geliştirebildiği ortaya çıkmaktadır.

*Programın tarafsız olduğunu düşünüyor musunuz?

K1: "Hayır biraz taraflı gibiydi."

K2: "Hayır, daha çok muhalefetin görüşlerini yansıtıyor."

K3: "Evet bence tarafsız bir yayındı."

K4: "Program taraflı olsa bile söylenilenlerin çoğu gerçek, sekiz ay işsiz kaldım."

K5: "Halk Tv tarafindan CHP'ye oy kazandırmak için yapılan bir program, tarafsız olduğu söylenemez." 
K6: "Kesinlikle taraflı bir yayındı."

K7: "Abartılmış ve uydurma haberlerle dolu bir programdı. Tarafsız olduğu söylenemez."

Görüldüğü üzere program katılımcıların büyük bir çoğunluğu tarafından taraflı olarak alımlanmıştır. Katılımcıların verdiği cevaplarda taraflı olarak algılanmasında programın muhalif yayın yapan Halk TV'de yayınlanmasının da etkili olduğu görülmüştür. Bir katılımcı hakim okuma yaparak programın etkisinde kalmış, diğer bir katılımcı ise müzakereli okuma yaparak programın taraflı olduğunu belirtmekle birlikte kişisel durumunun programda anlatılanlarla örtüștüğünü ifade etmiștir.

*Son dönemde ekonomik durumunuzda ne gibi değişimler oldu?

K1: "Kazancım döviz bazlı olduğu için alım gücüm arttı."

K2: "Fakirleștik."

K3: "Fiyatlar çok arttı, önceden birikim yapardık artık karnımızı zor doyuruyoruz."

K4: "işsiz kaldım."

K5: "Fakirleștik."

K6: "Kriz herkes gibi bizi de vurdu."

K7: "Fırsatçılar yüzünden her şey pahalılaştı."

Kişilerin son dönemde ekonomik durumlarında yaşanan değişim incelendiğinde Medya Mahallesi programı ile ilgili önceki sorulara verilen cevapların kişilerin sosyo-ekonomik durumlarıyla ilişkili olduğu görülmektedir. Bazı katılımcıların ise olaylara karşı daha çok hükumete yönelik program öncesinde de var olan tutumlarına uygun bir okuma gerçekleştirdiği görülmektedir.

*Program sonunda ülke ekonomisinin durumuna ya da hükumetin ekonomi alanındaki icraatlarına yönelik düşüncelerinizde herhangi bir değişiklik oldu mu?

K1: "Evet, beni etkilemiyor ama sanırım durum düşündüğümden de kötü."

K2: "Hayır fakat bazı düşüncelerimi destekledi."

K3: "Hükumetin israflı davrandığını yapılan saraylardan biliyordum ama devasa projelerin bu kadar zarar edebileceğini bilmiyordum."

K4: "Konuk görmezden gelinen işsizlik sorununu güzel anlattı fakat bunlar zaten biliniyordu."

K5: "Döviz rezervlerinin bu kadar azaldığını bilmiyordum, Cumhurbaşkanı 100 Milyar\$ rezervimiz var demiști."

K6: "Hayır herhangi bir değişiklik olmadı."

K7: "Hayır beni kandıramazlar."

Verilen cevaplar izleyicilerin sosyo-ekonomik özelliklerinin ve ideolojilerinin medya metinlerini farklı şekilde okumalarında etkili olduğunu göstermiştir. Kişinin içerisinde bulunduğu sosyo-ekonomik durum medya metinlerini okumada etkili olduğu gibi, baskın ideolojiler aynı medya metnine ve gerçekliğe farklı anlamlar yükleyebilmektedir.

\section{Sonuç}

Kültür, söylem, iktidar, ideoloji ve medya analizleri Kültürel Çalışmaların temel araștırma konularını oluşturmaktadır. Kültürel Çalıșmalar, farklı bağlamların sosyal problemlerine ve sorularına yanıt vermeye çalışmakta, medya analizlerini yorumsamacı kültür çalışmaları kapsamında gerçekleştirmektedir. Medya analizlerinin odak noktasında metinlerin ve kültürel pratiklerin anlamlarının sosyal dolaşıma bağlanması yer almaktadır (Alver, 2009, s. 32). 
İngiliz Kültürel Çalışmalar Ekolü, kitle iletişim araçlarını çağdaş kapitalizmin başlıca ideolojik kurumları olarak görmektedir (Hall, 1999a, 1999b; Shoemaker \& Reese, 1997). Fakat bu yaklaşım medya analizlerinde bireylerin medyadaki iletileri sorgulamadan kabul eden pasif bireyler olduğu düşüncesini reddeder. Ekol, medya çalışmalarında izleyiciyi aktif ve anlam oluşturabilme yetisine sahip bir özne olarak kabul etmektedir. Ekolün ön plana çıkardığı etkin izleyici teorisi, iletişim sürecinde izleyicilerin kendi kararlarına ve gerçeklerine medya metinlerinden ulaşmaya muktedir olduklarını ve medya metinlerini kodlandıkları şekilde değil, birçok anlama olanak veren farklı kodaçımlarıyla okuyabileceklerine vurgu yapmaktadır.

Stuart Hall'un "kodlama-kodaçımı" modeli medyanın özellikle de televizyonun hangi ideolojik iktidarı uygulamaya çalıştığını belirlemeyi amaçlamaktadır. Hall, analizlerinde özellikle televizyonun bölgeler, sınıflar ve kültürler arasındaki karmaşık toplum yapısında diğer toplumsal grupların yaşamına ilişkin enformasyonu ilettiğini ve ortak kod ve yorum çerçevesi sunduğunu belirtmektedir. Bu ortaklık, tamamen aynı olan anlam yapılarını değil, aksine gerçekliğin tanımını, yorumunu ve açıklamasını içermektedir (Alver, 2009, s. 47). Kültürel Çalışmalar, televizyona ve televizyon metinlerini analizine hatta diğer kitle iletişim araçlarına kıyasla aşırı önem vermiştir. Bir iktidar aygıtı olan ve kitleleri hem ideolojik hem de ekonomik açıdan yönlendirme işlevi bulunan televizyon Kültürel Çalışmaların öncülüğünde, aynı zamanda insanların istekleri doğrultusunda okudukları/ anlamlandırdıkları kültürel bir kaynak olarak da görülmektedir (Arık, 2008).

Bu çalışmada Halk TV'de 26.04.2019 tarihinde yayınlanan Medya Mahallesi adlı haber programının farklı sosyolojik, demografik ve ekonomik özelliklere sahip 7 izleyici tarafından nasıl alımlandığı ortaya çıkarılmaya çalışılmıştır. Örneklemin bu şekilde seçilme nedeni izleyicilerin medya metinlerini anlamlandırma sürecinde etkin olduğu ve farklı özelliklere sahip izleyicilerin aynı medya metinlerini farklı şekillerde anlamlandırabileceği varsayımına dayanmaktadır. Programın sunucusu Ayșenur Arslan'ın yorumu, programın konuk tercihi, ele alınan ekonomik konular ve konuk Murat Muratoğlu'nun AK Parti hükümetinin ekonomik icraatları ile ilgili değerlendirmeleri yoğun bir olumsuzlama taşımaktadır. Programın hakim kodu AK Parti hükumetinin ekonomi yönetiminde bașarısız olduğudur. Örnekleme dahil olan izleyicilerin büyük çoğunluğu programın kodlayıcılarının niyetinin farkında olduklarıyla ilgili anlamlar üretmiştir. Bu algının en büyük nedeni programın yayınlandığı Halk TV'nin katılımcılar tarafından taraflı bir yayın anlayıșına sahip olduğu düşüncesidir. İzleyiciler programın kendilerine vermek istediği mesajın farkındadır ve bu mesajlara yer yer direnebilmiştir. Çalışma sonucunda medya metinlerinde yer alan hakim kodların izleyicilerin ideolojik, sosyolojik ve ekonomik konumlarına göre farklı alımlandığı ortaya çıkmaktadır. Kişinin sosyo-ekonomik durumuna bağlı olarak bir izleyicinin olumlu olarak algıladığı bir mesajı başka bir izleyicinin oldukça olumsuz olarak algılayabildiği görülmüştür. Programın mesajlarının yorumlanmasında en büyük etkenin izleyicilerin siyasi tutumlarının olduğu anlaşılmıştır. AK Parti'ye karşı olumsuz görüşte olan izleyiciler programın sunduğu mesajları doğrudan benimserken AK Parti'ye karşı olumlu görüşe sahip izleyiciler programın sunduğu mesajlara karşıt bir okuma gerçekleştirmişlerdir. İzleyicilerin bir kısmı ise programda verilen mesajlar ile kendi yaşadıklarını birleştirerek müzakereli bir okuma geliştirmiştir. Çalışma, izleyicilerin televizyon iletileri karşısında yalnızca pasif bir tüketici olmadığını, etken konumda bulunduğunu ve iletilerle önemli oranda başa çıkarak alternatif anlamlar üretebildiğini ortaya koymuştur. 


\section{Etik Kurul İzni}

Akdeniz Üniversitesi Rektörlüğü Sosyal ve Beşeri Bilimler Bilimsel Araștırma ve Yayın Etiği Kurulu 16/10/2020 tarih ve 17 sayll toplantısında alınan karar çerçevesinde çalışma etik açıdan bir sakınca içermemektedir.

\section{Kaynakça}

Alver, F. (2009). Kültürel çalışmalarda medya metinlerinin okunmasi sürecinde izleyicinin konumlandirilmasi. In T. Şeker \& M. Şeker (Eds.), Terör ve Haber Söylemi (ss. 27-60). Konya: Literatürk Yayınları.

Alver, F. (2011). Gazetecilik bilimi ve kuramlari. İstanbul: Kalkedon Yayıncılık

Arık, M. (2004). Medya ve kültür çalişmalari kapsaminda kültürel çalişmalar ekolüne bir bakiş. In M. Işık (Ed.), Medyada Yeni Yaklaşımlar. Konya: Eğitim Yayınevi.

Arık, M. (2008). Raymond Williams. In M. Çoban (Ed.), Kadife karanlik İstanbul: Su Yayınevi.

Bilton, T., Bonnet, K., Jones, P., Lawson, T., Skinner, D., Stanworth, M., \& Webster, A. (2008). Sosyoloji. Siyasal Kitabevi: Ankara.

Casey, B., Casey, N., Calvert, B., French, L., \& Lewis, J. (2002). Television studies (The key concepts). London\&New York: Routledge.

Fiske, J. (1999). Popüler kültürü anlamak (S. İrvan, Trans.). Ankara: Ark Yayınları.

Hall, S. (1997). İdeoloji ve iletişim kurami, Medya, Kültür, Siyaset (S. İrvan Ed.). Ankara.

Hall, S. (1999a). Encoding-decoding", The cultural Studies reader. London: Routledge.

Hall, S. (1999b). İdeolojinin yeniden keşfi: Medya çalışmalarında baskı altında tutulanın geri dönüşü. In M. Küçük (Ed.), Medya, İktidar, İdeoloji (ss. 77-127). Ankara: Bilim ve Sanat.

Hall, S. (2005). Introduction to media studies at the centre: Some problematic and problems", culture, media, language (D. H. S. Hall, A. Lowe, P. Willis Ed.). Londra ve New York: Routledge.

İnal, A. (1996). Haberi okumak. İstanbul: Temuçin Yayınları.

Jensen, K. B., \& Rosengren, K. E. (2005). İzleyicinin peşindeki beş gelenek medya ve izleyici bitmeyen tartişma (Ș. Yavuz, Trans.). Ankara: Vadi Yayınları.

Morley, D. (1986). Cultural trasformations: The politics of resistance”, Popular culture and social relations (C. M. a. J. W. T. Bennett Ed.). London: Milton Keynes\& Open University Press.

Mutlu, E. (1994). İletişim sözlüğü. Ankara: Ark Yayınevi.

Özbek, M. (1994). Popüler kültür ve Orhan Gencebay arabeski. İstanbul: İletişim Yayınları

Shoemaker, P., \& Reese, S. (1997). İdeolojinin medya içeriği üzerindeki etkisi, medya, kültür ve siyaset (S. İrvan, Trans.). Ankara: Bilim ve Sanat Yayınları.

Şeker, T. (2009). 5N1K haber programının alımlama analizi. Selçuk İletişim Dergisi, 5(4), 105-117.

Şeker, T., \& Tiryaki, S. (2013). Savaş fotoğrafçısı filminin alımlama analizi. Global Media Journal, 6(1), 196-212. 
Turner, G. (1992). British cultural studies. London \& New York: Routledge.

Williams, R. (1980). Problems in materalism and culture. London: Verso-Pub.

Williams, R. (1990). Marksizm ve edebiyat (E. Tarım, Trans.). İstanbul: Adam.

Williams, R. (1993). Culture and society. London: The Hogharth Press. 


\title{
British Cultural Studies Tradition and the Reception Analysis of "Medya Mahallesi" News Program
}

\author{
Hakkı Akgün (Res. Asst.) \\ Emel Arık (Assoc. Prof. Dr.)
}

\section{Extended Abstract}

The Tradition of Cultural Studies has especially questioned the role of ideology in modern societies, and focused on how different ideological traditions form cultural practices. When audience or readers were once in a position where they were shepherdedconducted by the influence of the dominant discourse, together with the culturalists who affirm naturality and simplicity, the concept of active audience came to the agenda and plural readings took their place on the cultural map. Especially, Stuart Hall and subsequent names such as David Morley and Ien Ang focused on how the audience received the messages conveyed to them rather than media ideologies.

Reception studies towards the analysis of the reception processes of media audiences are based on Stuart Hall's encoding-decoding theory. Hall, one of the most important figures of the British Tradition of Cultural Studies, says that the media is one of the most influential ideological institutions of capitalism. The naturalized ideology is conveyed to society through mass media. While the media hides its ideological position and ensures the transfer of meanings to the masses with a natural and detached discourse, it assumes a function of legitimizing the values of dominant powers. Yet the struggle over meaning often involves a balance in which there are different winners and losers. Within this balance, sometimes the discourse of the government and sometimes the discourse of the public prevails. Media is one of the most important guarantors of this balance in modern societies.

The "encoding-decoding" concept by Stuart Hall is important for the individuals in terms of constructing their world of meaning with their own priorities, despite all the ideological dynamics of the media. According to Hall, messages transmitted from media centers with the motives of a certain ideology are sometimes decoded in the preferred way, sometimes in a controversial way and sometimes with an opposition. While in the preferred reading the decoding occurs in the way preferred by the dominant ideology, the controversial reading implies the deliberation of the text and a decoding which is both resisting and adaptive. On the other hand, the reader is fully aware of the transmitted ideological message and rejects the transmitted message with awareness in oppositional reading. In other words, despite all the wishes of the dominant ideology, individuals can decode the messages sent to them not in the preferred way, but in line with their own ideology (Hall, 1999a, p. 204).

This model is especially adapted to the messages transmitted from television, and it has demonstrated that the messages prepared on the axis of certain professional ideologies can often contain multiple meanings. Although media professionals skillfully hide their messages by concealing their ideological goals, the public has the ability to reject these messages in their own world of meaning. "Program producers can use all encoding skills, abilities and knowledge to encourage audiences to prefer certain meanings, but since decoding is not a passive but an active process, this "preference" is not a guarantee of the 
encoders' power, but an attempt of power; in other words, it is an offer that the audience will negotiate during the decoding process" (Mutlu, 1994, p. 220).

Hall's model suggests important clues about how television programs are perceived by the public. His model, which is molded by a perspective that grants the possession of power to the target audience as opposed to a communication model which attributes the power to the source, emphasizes on the public's freedom of choice. The main determinant of how media texts will be perceived in the eyes of society is not how they are presented, but how the public perceives them. Therefore, texts are always faced with the threat of being perceived differently than planned.

In this study, it was endeavored to reveal how the news program named Medya Mahallesi, broadcast on Halk TV on 26.04.2019, was received by seven viewers which have different sociological, demographic and economic characteristics. The reason for choosing the sample in this way is based on the assumption that the audience is active in the process of interpreting media texts and that viewers with different characteristics can interpret the same media texts in different ways. The comments of the program presenter Ayșenur Arslan, the guest preference of the program, the economic issues discussed, and the assessments of Murat Muratoglu, the guest of the program, related to the economic activities of the AK Party government, all bear an intense negation. The dominant code of the program is that the AK Party government is unsuccessful in the management of economy. The majority of the viewers included in the sample produced interpretations in relation to their awareness of the intention of program encoders. The most important reason for this perception is the opinion of the participants suggesting that Halk TV, where the program is broadcast, has a biased broadcasting mentality. The viewers are aware of the message the program wanted to convey to them, and they partially achieved to resist these messages. As a result of the study, it is revealed that the dominant codes in media texts are received differently according to the ideological, sociological and economic positions of the audience. It has been observed that, depending on the socioeconomic status of the person, a message that one viewer perceives positively can be perceived negatively by another viewer. It is understood that the most important reason factor in the interpretation of the messages in this program is the political attitudes of the audience. While viewers with a negative perception against the AK Party directly adopted the messages offered by the program, viewers with a positive perception of the AK Party made a reading opposed to the messages provided by the program. On the other hand, some of the viewers developed a negotiated reading by combining the messages given in the program with their own experiences. The study revealed that the audience is not just a passive consumer in the face of television messages but is in an active position and can produce alternative meanings by coping with the messages significantly.

Keywords: Journalism, Cultural Studies, Ideology, Reception Analysis.

Bu makale intihal tespit yazılımlarıyla taranmıştır. Intihal tespit edilmemiştir.

This article has been scanned by plagiarism detection softwares. No plagiarism detected.

Bu çalışmada "Yükseköğretim Kurumları Bilimsel Araştırma ve Yayın Etiği Yönergesi” kapsamında uyulması belirtilen kurallara uyulmuştur.

In this study, the rules stated in the "Higher Education Institutions Scientific Research and Publication Ethics Directive" were followed. 